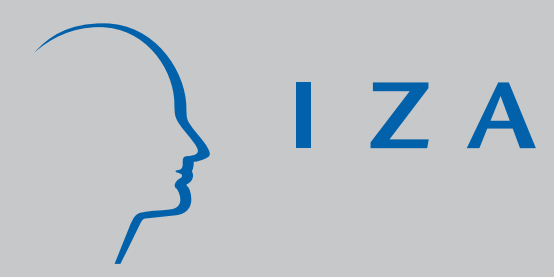

IZA DP No. 3122

Earnings-Tenure Profiles:

Tests of Agency and Human Capital Theories

Using Individual Performance Data

Xiao-Yuan Dong

Derek C. J ones

Takao Kato

October 2007 


\title{
Earnings-Tenure Profiles: Tests of Agency and Human Capital Theories Using Individual Performance Data
}

\author{
Xiao-Yuan Dong \\ University of Winnipeg \\ Derek C. Jones \\ Hamilton College, Mondragon University \\ and University of Michigan \\ Takao Kato \\ Colgate University, Columbia Business School, \\ University of Tokyo, Aarhus School of Business and IZA
}

Discussion Paper No. 3122

October 2007

\author{
IZA \\ P.O. Box 7240 \\ 53072 Bonn \\ Germany \\ Phone: +49-228-3894-0 \\ Fax: $+49-228-3894-180$ \\ E-mail: iza@iza.org
}

\begin{abstract}
Any opinions expressed here are those of the author(s) and not those of the institute. Research disseminated by IZA may include views on policy, but the institute itself takes no institutional policy positions.

The Institute for the Study of Labor (IZA) in Bonn is a local and virtual international research center and a place of communication between science, politics and business. IZA is an independent nonprofit company supported by Deutsche Post World Net. The center is associated with the University of Bonn and offers a stimulating research environment through its research networks, research support, and visitors and doctoral programs. IZA engages in (i) original and internationally competitive research in all fields of labor economics, (ii) development of policy concepts, and (iii) dissemination of research results and concepts to the interested public.
\end{abstract}

IZA Discussion Papers often represent preliminary work and are circulated to encourage discussion. Citation of such a paper should account for its provisional character. A revised version may be available directly from the author. 


\section{ABSTRACT \\ Earnings-Tenure Profiles: Tests of Agency and Human Capital Theories Using Individual Performance Data*}

By using a large new panel of individual data, including objective measures of worker performance, we provide some of the most rigorous evidence to date on several related dimensions of enduring debates surrounding upward-sloping earnings-tenure profiles. Most importantly we provide the first direct test of the relative validity of human capital and agency explanations in accounting for upward-sloping earnings-tenure profiles; our findings strongly support the agency view. Our second area of interest concerns employee ownership (many workers at our case are employee owners). Consistent with agency theory we find that earnings-tenure profiles for employee owners are not upward-sloping but horizontal. In addition we find that pay-performance sensitivities are substantially weaker for employee owners than for other workers. Finally we investigate the impact of residential policies in China. We find that again consistent with the agency view, earnings-tenure profiles are considerably steeper for urban workers than for migrant workers with far more limited alternative employment opportunities.

JEL Classification: J3, M5, L6

Keywords: earnings, tenure, seniority, performance, human capital, agency, employee ownership

Corresponding author:

Takao Kato

Department of Economics

Colgate University

13 Oak Drive

Hamilton, NY 13346

USA

E-mail: tkato@mail.colgate.edu

\footnotetext{
* The current version of the paper was completed while Kato was Velux Visiting Professor at ASB (Aarhus School of Business), and Kato is grateful for their hospitality. The authors are grateful to support from NSF SES-0522117.
} 


\section{Earnings-Tenure Profiles: Tests of Agency and Human Capital Theories Using Individual Performance Data}

\section{Introduction}

The existence of upward-sloping earnings tenure profiles is one of the most often observed empirical regularities in the field of labor economics around the world (for empirical surveys see, for example, Hutchens, 1989; Topel, 1991.) At the same time, the explanation for this observed regularity remains highly controversial with sharp disagreement surrounding, in particular, the respective roles of human capital and agency theories (e.g. Heckman, Lochner and Todd., 2005 and Altonji and Williams, 2005.) To a large degree, as in many areas in economics, the persistence of disputes reflects a sharp disconnect between key theoretical propositions and the data that are available to test these hypotheses - the gains from advances in econometric techniques and theory have been muted because of limited data (Griliches, 1994:2.) In this paper our use of new micro data that we have gathered enables us to undertake an econometric case study and provide some of the most rigorous evidence to date on several related dimensions of enduring debates surrounding upward sloping earnings-tenure profiles.

A primary interest concerns the field of human capital. That theory, as developed for example by Becker (1964), offers a well-known explanation for upward-sloping earnings-tenure profiles. While human capital has various forms, the main types are formal education and on-the-job-training. In turn, on-the-job-training involves employees learning both from formal training programs as well as via informal knowledge acquisition on the job (including both learning by doing and knowledge transfer from peers at their workplaces). As the worker spends more time on the job with the firm, her human capital (specific and general) will grow and hence her performance will improve. 
(For a discussion of the links between tenure, training and the formation of human capital see, e.g., Ryan, 2001, Lazear, 1998 ch. 6, and Koike, 2005 chs. 1-3). Thus, human capital theorists stress the importance of a worker's human capital accumulation through on-thejob training, and view his/her tenure as a good proxy for the level of human capital he/she has accumulated through on-the-job training. As such, the upward-sloping earningstenure profiles are interpreted as indicating that wages will rise with tenure because workers with longer tenure have more human capital (see, for instance, Hashimoto, 1981)

By contrast, agency theorists explain the phenomenon as a form of deferred compensation used to motivate employees and limit shirking. Upward-sloping earningstenure profiles, combined with a termination contract stipulating that shirking workers, if caught, will be fired are expected to provide sufficient incentives for workers not to shirk. In other words, shirking workers will face a sufficiently high probability of forfeiting an opportunity to receive a higher wage. For agency theorists, even after each worker's human capital is perfectly measured and controlled for, econometricians will still obverse upward-sloping earnings-tenure profiles (See, for example, Lazear, 1979, and Lazear and Moore, 1984 for this alternative agency theory). ${ }^{1}$

A simple and direct test of the relative validity of the two competing explanations is to estimate earnings-tenure profiles, and see if the earnings-tenure profiles are still sufficiently upward-sloping even after individual worker performance is controlled for. Nonetheless, such simple direct tests are extraordinarily scarce. In large part this is due to the limited availability of reliable individual worker performance data. A notable

\footnotetext{
${ }^{1}$ There is also a matching model interpretation of the upward-sloping earnings-tenure profiles (Jovanovic, 1979). For surveys of the empirical literature see, for example, Hutchens (1987and 1989).
} 
exception is Medoff and Abraham (1980) who use personnel records on all managerial and professional employees from two large manufacturing firms in the U.S. and provide evidence in favor of agency theorists. However, as the authors themselves acknowledge, a possible limitation of the study is the use of subjective performance evaluations as a measure of individual worker performance. ${ }^{2}$

It is against this backdrop that the key objective of this paper becomes clear. We use objective worker performance data to provide the first direct test of the relative validity of two competing explanations of upward-sloping earnings-tenure profiles.

Our empirical work is facilitated by our gaining rare access to individual records for all weavers who worked at any time during a year-long period at a textile firm (CHINATEXTILE) in the interesting case of China. We learned from our extensive field research at CHINATEXTILE over the last three years ${ }^{3}$ that CHINATEXTILE views output quality as the most important worker performance measure, and collects each weaver's defect rate (percentage of defective output produced by each weaver per week) consistently. We were able to persuade CHINATEXTILE to grant us full access to the crucial worker performance data as well as other personnel records (such as earnings and tenure) for all weavers during the 53-week period from the first week of April of 2003 to the last week of March of 2004.

${ }^{2}$ A number of innovative attempts have been made to overcome the lack of individual worker performance data and test the relative validity of the two competing theories indirectly by estimating production functions using firm-level or establishment-level data and deriving productivity-tenure profiles (see, for instance, Hellerstein and Neumark, 1995 and 2004 and Hellerstein, Neumark and Troske, 1999, and Fukao, et. al., 2006).

${ }^{3}$ Our approach is that of an econometric case study. For surveys of studies of this class see, for example, Ichniowski and Shaw (2003) and Jones, Kalmi and Kauhanen (2006). 
One of the two other, secondary questions we address concerns the impact of employee share ownership on earnings-tenure profiles. Ownership of shares by employees is a phenomenon that has grown rapidly in recent years around the world, including advanced capitalist economies (see for example Blasi and Kruse, 1991, and Blasi, Kruse and Bernstein, 2003). There has also been a surprising amount of employee ownership in China (e.g. Tseo, Hou , Zhang and Zhang ,2004) as well as in the former centrally planned economies where it has often been introduced as part of a privatization strategy (e.g. Uvalic and Vaughan-Whitehead, 1997.) A sizeable theoretical and empirical literature has also appeared that examines various issues relating to employee ownership, with much work focusing on the implications of employee ownership for enterprise productivity and usually finding beneficial productivity effects (e.g. Craig and Pencavel, 1995; Jones and Kato, 1995). In accounting for enhanced productivity, it is argued that employee ownership tends to align the interest of employees with that of the firm. In turn this argument implies that the wage for employee owners may not need to be as sensitive to worker performance measures as the wage paid to non-employee owners. In fact, total compensation for employee owners may well become excessively variable if the sensitivity of their wage to worker performance is as high as that of non-employee owners. For the same reason, the earnings-tenure profiles for employee owners may not need to be as upward-sloping as for other workers to prevent workers from pursuing their own interests at the cost of the well-being of the firm. Such hypotheses, however, remain untested.

Fortunately, at CHINATEXTILE almost 40 percent of the weavers are employee owners. Hence our individual data enable us to examine, for the first time, how earnings- 
tenure profiles are affected by employee ownership. Specifically, we can reliably estimate the earnings-tenure profiles and the pay-performance sensitivity for employee owners and other weavers separately.

The final question we investigate is how residential polices for urban registrants and rural migrant workers can be expected to affect earnings-tenure profiles. Issues surrounding the rural/urban divide in the Chinese labor market are recognized as a crucial policy issue in China and have attracted much attention in the literature-- see for instance Nielsen, et al. (2006) and Lu and Song (2006.) However, for the most part, empirical studies have used firm-level data and the ramifications of policy for matters such as earnings-tenure profiles have not been examined. By contrast, our individual data allow us to provide rigorous evidence for the first time on whether wage determination within the firm differs significantly between urban weavers and rural weavers. Specifically, we test two hypotheses. First, the literature on rural/urban divide in the Chinese labor market reports that job opportunities for rural migrant workers are more limited than for urban workers (for example, the lack of unemployment insurance makes it difficult for rural migrant workers to stay in a city and look for a new job). The opportunity cost of shirking on the job and getting fired is already quite high for rural migrant workers due to their limited alternative job opportunities. As a result, there is less need to make the earningstenure profiles steeper to make the cost of shirking and getting fired sufficiently high to prevent worker shirking.

The second hypothesis concerns the pay-performance linkage. All weavers in our sample have the same level of schooling (junior high school). However, due to the school quality difference between urban and rural schools, rural migrant workers tend to be less 
prepared for high quality work than urban workers (as shown later, on average rural workers lag behind urban workers in quality). ${ }^{4}$ The greater pay-performance sensitivity for rural workers may serve as a credible signal to rural workers of the importance of quality. Furthermore, the greater pay-performance sensitivity means more variable earnings and rural migrant workers with more limited alternative employment opportunities may be more likely to accept such variable earnings than urban workers. In short, we hypothesize that the pay-performance sensitivity may be greater for rural migrant workers than for urban registrants.

The structure of this paper is as follows. The following section provides an overview of our case that is accompanied by a presentation of basic descriptive statistics of our key variables. This is followed by a brief conceptual review. In the next two parts we detail our empirical strategy and present our findings. In a concluding section we consider the implications of our findings.

\section{The Case, Data and Descriptive Statistics}

Our case, CHINATEXTILE, is located in an area in which many textile firms are to be found in China, Shijiangzhuang, the capital of Hebei province. ${ }^{5}$ Originally the firm was state-owned and suffering from the financial crisis that affected many Chinese firms during the 1990's with outdated equipment, an aging workforce, and a shrinking market contributing to the firm's difficulties. The threat of bankruptcy led to ownership restructuring as an alternative solution to closure and the value of the firm's assets was

\footnotetext{
${ }^{4}$ See, for instance, Wang (1995).

${ }^{5}$ Our confidentiality agreement with CHINATEXTILE prohibits us from revealing the actual name of the firm.
} 
transferred completely to employees in $1998 .{ }^{6}$ During the study period the total labor force averaged about 3500 employees.

We collected several kinds of data from the case. These were collected during a lengthy study period when we visited the firm twice and met with and interviewed the Director of Human Resources, the Director of the Weaving Division, a line supervisor and two team leaders at the Weaving Division, and the Director of Data Management (who was in charge of all internal data). In addition, to get perspective from an outsider, we also interviewed a long-term consultant for CHINATEXTILE who has been observing the firm for many years. As well as collecting various performance and personnel data, we also deepened our knowledge of the case by collecting data from a survey that we designed and administered to all team leaders.

Our key data are a panel for ll $^{7} 297$ weavers who worked in CHINATEXTILE at any time during the 12 month period spanning the first week of April 2003 to the last week of March 2004. ${ }^{8}$ We chose this group of employees because an accurate objective measure of individual worker performance with little measurement error is available consistently for all workers during this period. In addition, we were able to match these worker performance data with weekly earnings data, using unique employee IDs.

\footnotetext{
${ }^{6}$ Employee ownership has been extensively used in China as part of a strategy to restructure state firms. By some estimates at least one third of restructured firms have some degree of employee ownership (National Statistics Bureau, September 2002), For a discussion of the role played by employee ownership in Chinese firms see Tseo, Hou , Zhang and Zhang (2004).

${ }^{7}$ By having data for all weavers, we are able to respond to key selection concerns that often plague econometric studies in this area.

${ }^{8}$ There were actually a dozen of weavers in our data who worked for only one week and less than 15 hours during the week. We have no reliable performance data for such weavers.
} 
Finally, we were able to secure additional personnel records and merge them into the performance data set.

A quick glance at the weaving workplace gives observers a first impression that the role of weavers in the production process is rather limited since the operation appears to be fully automated and various fabrics are produced by automated looms rather than by individual weavers. However, a closer look at the workplace reveals that weavers have significant responsibilities. For example, problems (such as broken threads) do occur from time to time and each weaver's main task is to pay close attention to her assigned loom machines (multiple loom machines are assigned to each weaver) and minimize the occurrence of such operational problems. If a problem does arise, each weaver is expected to solve the problem quickly and effectively. Good weavers will detect early signs of problems and make timely adjustments to the operational process so that problems will not fully materialize and hence no defective product will result. Should problems actually occur, the better weavers will solve them promptly and efficiently, so that there will be minimal production of defective output. Due to the problem-solving nature of their jobs, CHINATEXTILE constantly tells their weavers how important quality is, and implores them to work toward "zero defects".

In short, the nature of weaving technology and the problem-solving nature of a weaver's job at CHINATEXTILE indicates that the most relevant and crucial performance measure for weavers is quality. Importantly, CHINATEXTILE granted us full access to each weaver's weekly defect rate (percentage of defective output generated per week) for all 297 weavers who ever worked in the Weaving Division during the 12 month study period spanning the first week of April 2003 to the last week of March 2004 
As mentioned before, in 1998, CHINATEXTILE raised 28 million yuan of new capital by selling 26 million shares to their employees at the price of 1 yuan per share and held 2 million as collective shares. Share purchases were voluntary and employee shareholders received one free share for each share purchased. About 65 percent of all eligible employees decided to take the offer to become employee owners. The distribution of share ownership that emerged was considered to be too dispersed for effective incentives. Hence, with the approval by the employee congress, our case subsequently transferred 5 million shares to the board of directors (3 million shares were sold by employee owners and the remaining two million were sold from the collective share pool). Presently there are 2,338 shareholders including 1,756 employees (80\%), 329 retirees (11.8\%), and 253 former employees who have left the firm (8.2\%). No employee became a new employee owner during the period under study. Currently the board of directors, consisting of 15 members, own $21.6 \%$ of all outstanding shares and the CEO, owns 16.4\% (approximately 4.63 million yuan). Dividends have been distributed twice at the rate of $15 \%$ since 1998. Employee shares are transferable internally after being held for a period of 3 years. Share transactions are registered at the accounting office. Only a small number of shares have been sold by employee owners. CHINATEXTILE’s shareholder meetings are hold jointly with employee representative conferences, and the major decisions have been made, based on the rule of one share one vote.

The HR director at CHINATEXTILE stressed that two key factors were involved in the determination of a weaver's wage namely seniority and performance. Our subsequent wage regression analysis will reveal what the actual earnings data of 
individual weavers tell us about pay determination when our primary measure of performance is a measure of product quality, the defect rate.

Summary statistics are reported in Table 1 . On average weavers make about 150 yuan (about \$20) per week. Each weaver’s average weekly defect rate is 0.25 percent. Though the magnitude of the defect rate appears small, "zero defect” is extremely difficult to achieve. In fact, during the 53-week period, no weaver was able to achieve "zero defect". This also confirms our field observation that automated loom machines are far from perfect and problems do occur from time to time. Exclusive, focused and educated attention to these machines by weavers is indeed an integral part of a highperformance workplace. TENURE (the length of service with the firm) is calculated by counting for each weaver how many weeks she has been with the firm since she started working at CHINATEXTILE. Average tenure is found to be about 467 weeks. Furthermore, on average, 36 percent of weavers in the team are employee owners; and 37 percent are urban registrants.

\section{Empirical Strategy and Results: Human Capital vs. Agency Theory}

We begin by estimating the simplest earnings-tenure profile equation with individual worker fixed effects to control for time-invariant worker heterogeneity (such as unobserved innate ability of each worker):

$$
\begin{aligned}
& \ln \left(\text { WAGE }_{\mathrm{it}}=\alpha+\beta \text { TENURE }_{\mathrm{it}}+\gamma \text { TENURE }_{\mathrm{it}}{ }^{2}\right. \\
& +(\text { individual specific fixed effects })+(\text { monthly time dummy variables })+\mathrm{u}_{\mathrm{it}}
\end{aligned}
$$

Note that we also include 11 monthly time dummy variables to capture time-specific shocks to CHINATEXTILE that are common to all weavers. (There are actually 12 
monthly time dummy variables from April 2003 through March 2004 but we use the April 2003 time dummy variable as a reference month.).

The OLS estimates of Eq. (1) are reported in the first column of Table 2. The estimated coefficient on TENURE is positive and statistically significant at the 5 percent level, confirming the presence of upward-sloping earnings-tenure profiles for weavers at CHINATEXTILE, at least initially. The estimated coefficient on TENURE ${ }^{2}$ is negative and statistically significant at the 1 percent level, pointing to diminishing return to seniority. This finding of upward-sloping earnings-tenure profiles for weavers at CHINATEXTILE is thus consistent with similar findings for diverse workers in many different countries and institutional settings. ${ }^{9}$

We are now ready to present our main results. To test whether the estimated upward-sloping earnings-tenure profiles become flatter when we control for objective individual worker performance, we estimate

$$
\ln (\text { WAGE })_{\mathrm{it}}=\alpha+\beta \text { TENURE }_{\mathrm{it}}+\gamma \text { TENURE }_{\mathrm{it}}{ }^{2}+\eta \text { DEFRATE }_{\mathrm{it}}+\lambda \text { DEFRATE }_{\mathrm{it}}{ }^{2}
$$

+ (individual specific fixed effects) + (monthly time dummy variables) $+\mathrm{u}_{\mathrm{it}}$

Note that we include the square term of DEFRATE to capture a possible non-linear relationship between DEFRATE and ln(WAGE).

The last column of Table 2 reports the OLS estimates of Eq. (3). First, the estimated coefficient on DEFRATE is negative and significant at the 1 percent level, confirming our field notes from interviews with personnel at CHINATEXTILE that

\footnotetext{
${ }^{9}$ For surveys of the empirical literature see for instance Hutchens (1989) and Topel (1991). The empirical literature appears to have been reenergized lately by the development of employer-employee matched data. Unfortunately the employer-employee matched data do not include information on individual worker performance, and hence do not allow for direct test of the relative validity of the human capital theory vs. the agency theory.
} 
worker performance of individual weavers in the area of product quality is an important determinant of pay. The estimated coefficient on the square term of DEFRATE is positive and significant at the 1 percent level, supporting our prior expectation of diminishing return to performance, although the concavity of the earnings-performance curve is quite weak. In fact, the slope of the earnings-performance curve, assessed at the mean value of DEFRATE which is given by $\eta+2 \lambda$ (Mean of DEFRATE), turned out to be very close to the estimated coefficient on DEFRATE (१). Using the estimated slope of the earnings-performance curve assessed at the mean value of DEFRATE, we can gauge the magnitude of the sensitivity of pay to performance. For example, if the average weaver slacks off, pays less focused attention to her assigned loom machines, and hence her DEFRATE rises by one standard deviation (0.347), her weekly earnings will be cut by 8 percent.

Second and most importantly the estimated coefficients on TENURE and TENURE $^{2}$ in the last column of Table 2 are very close to those reported in the second column. It turns out that controlling for objective worker performance changes the slope of the earnings-tenure profiles very little. Hence our evidence favors agency theory over human capital theory.

We produce Figure 1, based on the estimated coefficients on TENURE and TENURE $^{2}$. The figure shows how the slopes of the earnings-tenure profiles change as weavers spend more time at the firm. Initially, one additional week of tenure will result in an increase of weekly earnings by 0.4 percent. As TENURE rises, returns to seniority will diminish. However, the pace at which returns to seniority diminishes is rather slow. According to our estimates, it will take 2,000 weeks (almost 40 years) for returns to 
seniority to reach zero. Since as in most firms in China, there is mandatory retirement at CHINATEXTILE (60 for men and 55 for women), our finding favors Lazear (1979)’s explanation for mandatory retirement as a solution to senior workers making more than what they produce.

The rest of Table 2 shows the robustness of our results. It is plausible that higher wages cause better worker performance (for example, the efficiency wage hypothesis) rather than better performance causing higher wages. To account for possible reverse causality issue we run two additional regressions. First, we consider a lagged worker performance measure instead of a contemporaneous measure. As shown in the third column of Table 2, the results using the lagged worker performance measure are similar to those using the contemporaneous measure, pointing to the robustness of our key findings.

Second, we consider an alternative specification in which we explicitly control for the efficiency wage effect on performance by adding DEFRATE and DEFRATE ${ }^{2}$ in the following week to Eq. (2). The last column of Table 2 shows the OLS estimates for such an alternative specification. The estimated coefficient on DEFRATE in the following week is negative and significant at the 1 percent level and, likewise, the estimated coefficient on DEFRATE ${ }^{2}$ in the following week is positive and significant at the 1 percent level. As such, we find some evidence for the efficiency wage effect on performance (or higher weekly earnings this week will lead to better performance next week). Nevertheless, the estimated coefficients on DEFRATE and DEFRATE ${ }^{2}$ this week are still negative and positive respectively and both statistically significant at the 1 percent level. In fact, a quick comparison between the second column and fourth column 
of Table 2 reveals that the original estimates of Eq. (2) are robust to the inclusion of DEFRATE and DEFRATE ${ }^{2}$ in the following week. In other words, even after controlling for the efficiency wage effect, we still find evidence of a significant pay-performance link.

Finally, to re-examine further our conclusion that upward-sloping earnings-tenure profiles have more to do with incentives than with human capital accumulation through on-the-job training, we estimate the performance-tenure profiles:

$\operatorname{DEFRATE}_{\mathrm{it}}=\alpha+\beta \mathrm{TENURE}_{\mathrm{it}}+\gamma \mathrm{TENURE}_{\mathrm{it}}^{2}$

+ (individual specific fixed effects) + (monthly time dummy variables) $+\mathrm{u}_{\mathrm{it}}$ The first column of Table 3 reports the OLS estimates of Eq. (4) (the linear specification is also reported). By finding no evidence of a significant performance-tenure link, this further confirms that the on-job-training human capital theory is less relevant to our weavers at CHINATEXTILE. The rest of the table reports findings that explore if significant performance-tenure linkages are found by disaggregating all weavers into different groups (e.g., employee owners vs. non-employee owners as well as urban registrants vs. rural migrants). As shown in the table, the absence of a significant performance-tenure linkage appears to be universal.

\section{Empirical Strategy and Results: Effects of Ownership and the Urban/Rural Divide}

Earlier we noted how agency theory implies that earnings-tenure profiles and payperformance sensitivities may differ between employee-owner workers and other workers. We also hypothesized how and why earnings-tenure profiles and pay- 
performance sensitivities might be expected to differ between urban registrants and rural migrant workers in China. Before examining such possible heterogeneity in pay determination more rigorously, we begin by comparing some key variables between the two groups of workers.

As shown in Table 4, TENURE of the average employee owner is about twice as long as that of the average non-employee owner (711 weeks vs. 328 weeks); and employee owners earn more than non-employee owners (152 vs. 144 yuan). On the other hand, there is no statistically significant difference in objective performance (DEFRATE) between employee owners and other weavers.

Turning to urban registrant and rural migrant weavers, those two groups of workers differ significant in all three areas: urban registrants have longer tenure (707 vs. 323); earn more (151 vs. 144$)$; and perform better (0.23 vs. 0.25 ) than rural migrant workers. In addition, there is an overlap between employee owners and urban workers (for example, 67 percent of employee owners are urban workers).

To test whether earnings-tenure profiles and pay-performance sensitivities differ significantly between employee owners and other workers, we estimate the following augmented earnings equations with the relevant interaction terms:

$$
\begin{aligned}
& \ln \left(\text { WAGE }_{i \mathrm{it}}=\alpha+\beta \text { TENURE }_{\mathrm{it}}+\gamma \text { TENURE }_{\mathrm{it}}{ }^{2}+\eta \text { DEFRATE }_{\mathrm{it}}+\lambda \text { DEFRATE }_{\mathrm{it}}{ }^{2}\right. \\
& +\beta_{\mathrm{E}} \mathrm{ESOP}_{\mathrm{it}} * \mathrm{TENURE}_{\mathrm{it}}+\gamma_{\mathrm{E}} \mathrm{ESOP}_{\mathrm{it}}{ }^{*} \mathrm{TENURE}_{\mathrm{it}}{ }^{2} \\
& +\eta_{\mathrm{E}} \mathrm{ESOP}_{\mathrm{it}}{ }^{*} \text { DEFRATE }_{\mathrm{it}}+\lambda_{\mathrm{E}} \mathrm{ESOP}_{\mathrm{it}}{ }^{*} \text { DEFRATE }_{\mathrm{it}}{ }^{2} \\
& +(\text { individual specific fixed effects })+(\text { monthly time dummy variables })+\mathrm{u}_{\mathrm{it}}
\end{aligned}
$$

Likewise for the possible urban/rural divide, we estimate:

$$
\ln \left(\text { WAGE }_{\mathrm{it}}=\alpha+\beta \text { TENURE }_{\mathrm{it}}+\gamma \text { TENURE }_{\mathrm{it}}{ }^{2}+\eta \text { DEFRATE }_{\mathrm{it}}+\lambda \text { DEFRATE }_{\mathrm{it}}{ }^{2}\right.
$$


$+\beta_{\mathrm{E}} \mathrm{URBAN}_{\mathrm{it}} * \mathrm{TENURE}_{\mathrm{it}}+\gamma_{\mathrm{E}} \mathrm{URBAN}_{\mathrm{it}} *$ TENURE $_{\mathrm{it}}{ }^{2}$

$+\eta_{\mathrm{E}} \mathrm{URBAN}_{\mathrm{it}}{ }^{*}$ DEFRATE $_{\mathrm{it}}+\lambda_{\mathrm{E}} \mathrm{URBAN}_{\mathrm{it}}{ }^{*}$ DEFRATE $_{\mathrm{it}}{ }^{2}$

+ (individual specific fixed effects) + (monthly time dummy variables) $+\mathrm{u}_{\mathrm{it}}$

Table 5 summarizes the OLS estimates of Eqs. (4) and (5). The estimated coefficient on an interaction term involving ESOP and TENURE is negative and significant at the 1 percent level and the estimated coefficient on an interaction term involving ESOP and TENURE ${ }^{2}$ is positive and also statistically significant at the 1 percent level. The earnings-tenure linkage is significantly weaker for employee owners than for other weavers. In fact, the coefficient on TENURE for employee owners, which is equal to $\beta+\beta_{\mathrm{E}}$, also turns out to be not significantly different from zero. Likewise the coefficient on TENURE ${ }^{2}$ which is equal to $\gamma+\gamma_{\mathrm{E}}$, turned out to be also not significantly different from zero. In other words, earnings-tenure profiles for employee owners are not upward-sloping but horizontal. As such, our findings support the hypothesis that earnings-tenure profiles for employee owner workers (whose interests are better aligned with those of the firm) need not be upward-sloping to prevent them from pursuing their own interests at the cost of the well-being of the firm.

Regarding the pay-performance sensitivity, the estimated coefficient on ESOP*DEFRATE is positive and statistically significant at the 1 percent level and the estimated coefficient on ESOP*DEFRATE ${ }^{2}$ is negative and statistically significant at the 1 percent level. The absolute value of the coefficient on DEFRATE for employee owners (which is given by $\left|\eta+\eta_{E}\right|$ ) is considerably smaller (0.135 as opposed to 0.342 ) although still significantly different from zero at the 1 percent level. Similarly, the absolute value of the coefficient on DEFRATE ${ }^{2}$ for employee owners $\left(=\left|\lambda+\lambda_{E}\right|\right)$ is smaller ( 0.005 vs. 
0.019) although still significantly different from zero. Using these coefficients, we calculate the sensitivity of pay to performance assessed at the mean value of DEFRATE for employee owners and other workers. The resulting pay-performance sensitivity estimates are $0.133(=0.135-0.005 * 2 * 0.241)$ for employee owners and $0.333(=0.342$ $0.019 * 2 * 0.250$ ) for other workers, implying that quality deterioration by one standard deviation ( 0.381 for employee owners and 0.326 for other workers) will be penalized with a wage cut of $5 \%$ for employee owners yet with a substantially greater wage cut of $11 \%$ for other workers).

In sum, the pay-performance sensitivity is found to be substantially weaker for employee owners than for other workers. Hence our findings provide support for the proposition that, since employee ownership tends to align the interest of employees with that of the firm, wages for employee owners need not be as sensitive to worker performance measures as the wage that for non-employee owners. In fact, total compensation for employee owners may well become excessively variable if the sensitivity of wage to worker performance were as high as that for non-employee owners.

Finally, the second column of Table 5 shows the OLS estimates of Eq. (5). The estimated coefficient on URBAN*TENURE is positive and statistically significant at the 5 percent level and the estimated coefficient on URBAN* TENURE ${ }^{2}$ is negative and statistically significant at the 5 percent level. Earnings-tenure profiles are found to be considerably steeper for urban workers than for rural migrant workers at least initially. For example, initially one additional week of tenure will result in a 0.4-percent increase in weekly earnings for urban workers whereas one additional week of tenure will lead to a 0.2-percent rise in weekly earnings for rural migrant workers. Since the earnings-tenure 
profiles are more concave for urban workers than for rural workers, the difference in the slope of the earnings-tenure profiles will eventually disappear (according to our estimates, the difference will disappear around 600 weeks of TENURE). In short, at least for the first 600 weeks, the earnings-tenure profiles are steeper for urban workers than for rural migrant workers, confirming our hypothesis that urban workers with better alternative employment opportunities need steeper earnings-tenure profiles to prevent them from shirking.

With regard to the pay-performance sensitivity, as expected, the estimated coefficient on URBAN*DEFRATE is positive and the coefficient on URBAN*DEFRATE ${ }^{2}$ is negative; both are statistically significant at the 1 percent level. Using the same formulae as used for employee owners vs. other workers, the payperformance sensitivity assessed at the mean value of DEFRATE for urban workers is estimated to be 0.122 whereas for rural migrant workers it is estimated to be 0.328 . A one-standard deviation increase in DEFRATE will be met with a penalty of a 3 percent wage cut for urban workers whereas a standard deviation increase in DEFRATE will result in a hefty penalty of a 13 percent wage cut for rural workers. In other words, findings support the hypothesis that rural migrant workers are faced with much stronger incentives to improve quality and to tolerate more variable earnings than urban workers. This suggests that rural migrant workers with lower quality schooling need to be made more aware of the importance of quality and to learn to improve quality than do urban workers and at the same time they will tolerate more variable earnings due to their much limited alternative employment opportunities than urban workers. 


\section{$\underline{\text { VI. Conclusions }}$}

While the existence of upward-sloping earnings tenure profiles is one of the most often observed empirical regularities in the field of labor economics around the world, the explanation for this observed regularity remains highly controversial with sharp disagreement surrounding, in particular, the respective roles of human capital and agency theories. For the first time that we are aware of, we are able to use a large new panel of individual data, including objective measures of worker performance, and thus we are able to provide what we believe is some of the most rigorous evidence to date on three related dimensions of enduring debates surrounding upward-sloping earnings-tenure profiles.

Most importantly we provide the first direct test of the relative validity of human capital and agency explanations in accounting for upward-sloping earnings-tenure profiles; our findings strongly support the agency view. Our second area of interest concerns employee ownership (and many workers at our case are employee owners.) Consistent with agency theory we find that earnings-tenure profiles for employee owners are not upward-sloping but horizontal. In addition we find that pay-performance sensitivities are substantially weaker for employee owners than for other workers. Finally we investigate the impact of residential policies in China. We find that again consistent with the agency view, earnings-tenure profiles are considerably steeper for urban workers than for migrant workers with far more limited alternative employment opportunities.

At the same time we are aware that ours is a case study and that one must be cautious in generalizing findings, especially to other institutional contexts. Equally, we note that there are other areas in which a significant set of econometric case studies has 
provided important contributions with broadly similar findings. One example is the work on the effects of piece rates (e.g. Lazear, 2000, Kleiner and Helper, 2003, Fernie and Metcalf, 1999, Paarsh and Shearer, 1999, Knez and Simester, 2001, and Bandiera, Barankay and Rasul, 2005.) As more studies based on disaggregated data sets similar to that gathered from CHINATEXTILE become available, we await to see whether a pattern of evidence on the nature and determinants of earnings-tenure profiles emerges that corroborates the picture presented in this paper. 


\section{References}

Altonji, Joseph G. and Williams, Nicolas. "Do Wages Rise with Job Seniority? A Reassessment." Industrial and Labor Relations Review, 2005, 58(3), pp. 370-97.

Bandiera, Oriana; Barankay, Iwan and Rasul, Imran. "Social Preferences and the Response to Incentives: Evidence from Personnel Data." Quarterly Journal of Economics, 2005, 120(3), pp. 917-62.

Becker, Gary S. Human Capital: A Theoretical and Empirical Analysis, with Special Reference to Education. Chicago: University of Chicago Press, 1964.

Blasi, Joseph; Kruse, Douglas and Bernstein, Aaron. In the Company of Owners: The Truth About Stock Options (and Why Every Employee Should Have Them). New York: Basic Books, 2003.

Blasi, Joseph Raphael and Kruse, Douglas Lynn. The New Owners: The Mass Emergence of Employee Ownership in Public Companies and What It Means to American Business. New York: Harper Collins, Harper Business, 1991.

Craig, Ben and Pencavel, John. "Participation and Productivity: A Comparison of Worker Cooperatives and Conventional Firms in the Plywood Industry." Brookings Papers on Economic Activity, 1995, 0(0), pp. 121-60.

Fernie, Sue and Metcalf, David. "It's Not What You Pay It's the Way That You Pay It and That's What Gets Results: Jockeys' Pay and Performance." Labour, 1999, 13(2), pp. 385-411.

Fukao, Kyoji; Kambayashi, Ryo; Kawaguchi, Daiji; Kwan, Hyeog Ug; Kim, Young Gak and Yokoyama, Izumi. "Deferred Compensation: Evidence from Employer-Employee Matched Data from Japan," Hitotsubashi Institute of Economic Research, 2006.

Griliches, Zvi. "Productivity, R\&D, and the Data Constraint." American Economic Review, 1994, 84(1), pp. 1-23.

Hashimoto, Masanori. "Firm-Specific Human Capital as a Shared Investment." American Economic Review, 1981, 71(3), pp. 475-82.

Heckman, James J.; Lochner, Lance and Todd, Petra E. "Earnings Functions, Rates of Return and Treatment Effects: The Mincer Equation and Beyond," IZA Discussion Paper No.1700, 2005.

Hellerstein, Judith K. and Neumark, David. "Are Earnings Profiles Steeper Than Productivity Profiles? Evidence from Israeli Firm-Level Data." Journal of Human Resources, 1995, 30(1), pp. 89-112.

- "Production Function and Wage Equation Estimation with Heterogeneous Labor: Evidence from a New Matched Employer-Employee Data Set," National Bureau of Economic Research, Inc, NBER Working Papers: 10325, 2004.

Hellerstein, Judith K.; Neumark, David and Troske, Kenneth R. "Wages, Productivity, and Worker Characteristics: Evidence from Plant-Level Production Functions and Wage Equations." Journal of Labor Economics, 1999, 17(3), pp. 409-46.

Hutchens, Robert M. "Seniority, Wages and Productivity: A Turbulent Decade." Journal of Economic Perspectives, 1989, 3(4), pp. 49-64.

. "A Test of Lazear's Theory of Delayed Payment Contracts." Journal of Labor Economics, 1987, 5(4), pp. 70. 
Ichniowski, Casey and Shaw, Kathryn. "Beyond Incentive Pay: Insiders' Estimates of the Value of Complementary Human Resource Management Practices." Journal of Economic Perspectives, 2003, 17(1), pp. 155-80.

Jones, Derek C.; Kalmi, Panu and Kauhanen, Antti. "Human Resource Management Policies and Productivity: New Evidence from an Econometric Case Study." Oxford Review of Economic Policy, 2006, 22(4), pp. 526-38.

Jones, Derek C. and Kato, Takao. "The Productivity Effects of Employee StockOwnership Plans and Bonuses: Evidence from Japanese Panel Data." American Economic Review, 1995, 85(3), pp. 391-414.

Jovanovic, Boyan. "Job Matching and the Theory of Turnover." Journal of Political Economy, 1979, 87(5), pp. 972-90.

Kleiner, Morris and Helper, Susan. "Changing Incentives for Production Employees: Impacts on Establishment Economic Outcomes and Worker Satisfaction," Paper presented at the 55th IRRA meeting, Washington, D.C., 2003.

Knez, Marc and Simester, Duncan. "Firm-Wide Incentives and Mutual Monitoring at Continental Airlines." Journal of Labor Economics, 2001, 19(4), pp. 743-72.

Koike, Kazuo. Shigoto No Keizaigaku (Economics of Work). Tokyo: Toyo Keizai, 2005.

Lazear, Edward P. "Performance Pay and Productivity." American Economic Review, 2000, 90(5), pp. 1346-61.

. Personnel Economics for Managers. New York; Chichester and Toronto: Wiley, 1998.

. "Why Is There Mandatory Retirement?" Journal of Political Economy, 1979, 87(6), pp. 1261-84.

Lazear, Edward P. and Moore, Robert L. "Incentives, Productivity, and Labor Contracts." Quarterly Journal of Economics, 1984, 99(2), pp. 275-96.

. "Incentives, Productivity, and Labor Contracts." Quarterly Journal of Economics, 1984, 99(2), pp. 275.

Lu, Zhigang and Song, Shunfeng. "Rural-Urban Migration and Wage Determination: The Case of Tianjin, China." China Economic Review, 2006, 17(3), pp. 337-45.

Medoff, James L. and Abraham, Katharine G. "Experience, Performance, and Earnings." Quarterly Journal of Economics, 1980, 95(4), pp. 703-36.

Nielsen, Ingrid; Nyland, Chris; Smyth, Russell; Zhang, Mingqiong and Zhu, Cherrie Jiuhua. "Effects of Intergroup Contact on Attitudes of Chinese Urban Residents to Migrant Workers." Urban Studies, 2006, 43(3), pp. 475-90.

Paarsch, Harry J. and Shearer, Bruce S. "The Response of Worker Effort to Piece Rates: Evidence from the British Columbia Tree-Planting Industry." Journal of Human Resources, 1999, 34(4), pp. 643-67.

Ryan, Paul. "The School-to-Work Transition: A Cross-National Perspective." Journal of Economic Literature, 2001, 39(1), pp. 34-92.

Topel, Robert H. "Specific Capital, Mobility, and Wages: Wages Rise with Job Seniority." Journal of Political Economy, 1991, 99(1), pp. 145-76.

Tseo, George K. Y.; Hou Gui Sheng; Peng-zhu, Zhang and Lihai, Zhang. "Employee Ownership and Profit Sharing as Positive Factors in the Reform of Chinese StateOwned Enterprises." Economic and Industrial Democracy, 2004, 25(1), pp. 14777. 
Uvalic, Milica and Vaughan-Whitehead, Daniel. "Creating Employee Capitalism in Central and Eastern Europe," Privatization Surprises in Transition Economies: Employee-Ownership in Central and Eastern Europe. Cheltenham, U.K. and Lyme, N.H.: Elgar; distributed by American International Distribution Corporation, Williston, Vt., 1997, 1-48.

Wang, Jianjun. "An Empirical Study of Student Science Achievement in the People's Republic of China.," U.S.California, 1995. 
Table 1 Summary Statistics

\begin{tabular}{|l||l|r|r|r||}
\hline Variable & Definition & Mean & S.D. & N \\
\hline \hline WAGE & Weekly earnings & 146.740 & 32.905 & 10082 \\
TENURE & length of service with CHINATEXTILE (in weeks) & 466.517 & 301.158 & 10082 \\
DEFRATE & percent of defective cloth produced per week (\%) & 0.247 & 0.347 & 10082 \\
ESOP & $=1$ if the weaver owns the stock of the firm, 0 otherwise. & 0.363 & 0.481 & 10082 \\
URBAN & $=1$ if the weaver is registered as an urban resident, 0 otherwise. & 0.374 & 0.484 & 10082 \\
\hline
\end{tabular}

Source: All data provided by CHINATEXTILE. Data are for 297 weavers at CHINATEXTILE

during the 53-week period from the first week of April, 2003 to the last week of March, 2004.

Note: All summary statistics are based on a pooled cross-sectional time series dataset on 297 weavers

over the 53-week period from the first week of April, 2003 to the last week of March, 2004. 
Table 2 Fixed Effect Estimates of the Earnings-Tenure Profiles

(Dependent variable=log of WAGE)

\begin{tabular}{|c|c|c|c|c|c|c|c|c|}
\hline \multirow[b]{2}{*}{ Variable } & \multicolumn{2}{|l|}{ (i) } & \multicolumn{2}{|l|}{ (ii) } & \multicolumn{2}{|l|}{ (iii) } & \multicolumn{2}{|l|}{ (iv) } \\
\hline & Coefficient & S.E. & Coefficient & S.E. & Coefficient & S.E. & Coefficient & S.E. \\
\hline TENURE & $0.0049 * *$ & \begin{tabular}{|l|}
0.0021 \\
\end{tabular} & $0.0043 * *$ & \begin{tabular}{|l|}
0.0021 \\
\end{tabular} & $0.0036 *$ & \begin{tabular}{|l|}
0.0020 \\
\end{tabular} & $0.0036 *$ & 0.0021 \\
\hline DEFRATE & & & $-0.263 * * *$ & 0.016 & & & $-0.218 * * *$ & 0.017 \\
\hline DEFRATE $^{2}$ & & & $0.014 * * *$ & 0.001 & & & $0.012 * * *$ & 0.001 \\
\hline DEFRATE $_{-1}$ & & & & & $-0.189 * * *$ & 0.015 & & \\
\hline DEFRATE $_{+1}$ & & & & & & & $-0.043 * * *$ & 0.017 \\
\hline DEFRATE $_{+1}{ }^{2}$ & & & & & & & $0.003 * * *$ & 0.001 \\
\hline $\mathrm{R}^{2}$ & & 0.378 & & 0.395 & & 0.368 & & 0.378 \\
\hline $\mathrm{N}$ & & 10082 & & 10082 & & 9785 & & 9785 \\
\hline
\end{tabular}

Source: All data provided by CHINATEXTILE. Data are for 297 weavers at CHINATEXTILE

during the 53-week period from the first week of April, 2003 to the last week of March, 2004.

Notes:

All models include individual fixed effects and monthly time dummy variables.

***statistically significant at the $1 \%$ level

**statistically significant at the $5 \%$ level 
Table 3 Fixed Effect Estimates of the Performance-Tenure Link (Dependent variable=DEFRATE)

\begin{tabular}{|c|c|c|c|c|c|c|c|c|c|c|}
\hline \multirow[b]{2}{*}{ Variable } & & & \multicolumn{4}{|c|}{$\mathrm{X}=\mathrm{ESOP}$} & \multicolumn{4}{|c|}{$\mathrm{X}=\mathrm{URBAN}$} \\
\hline & Coefficient S.E. & Coefficient S.E. & Coefficien & & Coefficient & S.E. & Coefficient : & S.E. & Coefficient & S.E. \\
\hline TENURE & $0.0004 \quad 0.0022$ & -0.00002 & 0.0002 & 0.0022 & -0.0001 & 0.0022 & 0.0004 & 0.0022 & 0.0001 & 0.0022 \\
\hline TENURE $^{2}$ & & 0.00000040 .0000003 & & & 0.0000004 & 0.0000005 & & & 0.0000004 & 0.0000005 \\
\hline X*TENURE & & & 0.0006 & 0.0004 & 0.001 & 0.001 & 0.0001 & 0.0004 & -0.001 & 0.001 \\
\hline $\mathrm{X}^{*} \mathrm{TENURE}^{2}$ & & & & & -0.000001 & 0.000001 & & & 0.000001 & 0.000001 \\
\hline $\mathrm{R}^{2}$ & 0.410 & 0.410 & & 0.410 & & 0.410 & & 0.410 & & 0.410 \\
\hline $\mathrm{N}$ & 10082 & 10082 & & 10082 & & 10082 & & 10082 & & 10082 \\
\hline
\end{tabular}

Source: All data provided by CHINATEXTILE. Data are for 297 weavers at CHINATEXTILE during the 53-week period from the first week of April, 2003 to the last week of March, 2004.

Notes:

All models include individual fixed effects and monthly time dummy variables. 
Table 4 Employee Owners and Urban Weavers

\begin{tabular}{|c|c|c|c|c|c|c|c|c|c|c|c|c|}
\hline \multirow[b]{2}{*}{ Variable } & \multicolumn{3}{|c|}{$\mathrm{ESOP}=1$} & \multicolumn{3}{|c|}{ ESOP $=0$} & \multicolumn{3}{|c|}{ URBAN=1 } & \multicolumn{3}{|c|}{ URBAN $=0$} \\
\hline & Mean & S.D. & $\mathrm{N}$ & Mean & S.D. & $\mathrm{N}$ & Mean & S.D. & $\mathrm{N}$ & Mean & S.D. & $\mathrm{N}$ \\
\hline WAGE & $\mid 152.067 * * *$ & 30.972 & 3656 & 143.709 & 33.583 & 6426 & $150.892 * * *$ & 31.427 & 3767 & 144.263 & 33.515 & 66315 \\
\hline TENURE & $710.753 * * *$ & 224.645 & 3656 & 327.562 & 245.646 & 6426 & $707.278 * * *$ & 277.562 & 3767 & 322.899 & 208.909 & 6315 \\
\hline DEFECT & 0.241 & 0.381 & 3656 & 0.250 & 0.326 & 6426 & $0.234 * * *$ & 0.270 & 3767 & 0.254 & 0.386 & 6315 \\
\hline
\end{tabular}

Source: All data provided by CHINATEXTILE. Data are for 297 weavers at CHINATEXTILE

during the 53-week period from the first week of April, 2003 to the last week of March, 2004.

Note: All summary statistics are based on a pooled cross-sectional time series dataset on 297 weavers

over the 53-week period from the first week of April, 2003 to the last week of March, 2004.

***statistically significant difference between the two groups at the $1 \%$ level 
Table 5 Fixed Effect Estimates of the Wage-Performance Link and Wage-Tenure Profiles: ESOP workers vs. non-ESOP workers and Urban vs. Rural Workers

(Dependent variable=log of WAGE)

\begin{tabular}{|c|c|c|c|c|}
\hline \multirow[b]{2}{*}{ Variable } & \multicolumn{2}{|l|}{$\mathrm{X}=\mathrm{ESOP}$} & \multicolumn{2}{|l|}{$\mathrm{X}=\mathrm{URBAN}$} \\
\hline & Coefficient & S.E. & Coefficient & S.E. \\
\hline TENURE & $0.0047 * *$ & 0.0021 & $0.0038 *$ & 0.0021 \\
\hline TENURE $^{2}$ & $-0.0000012 * * *$ & 0.0000004 & -0.00000014 & 0.00000051 \\
\hline DEFRATE & $-0.342 * * *$ & 0.020 & $-0.337 * * *$ & 0.020 \\
\hline DEFRATE $^{2}$ & $0.019 * * *$ & 0.001 & $0.018 * * *$ & 0.001 \\
\hline $\mathrm{X} *$ TENURE & $-0.0024 * *$ & 0.0010 & $0.0022 * *$ & 0.0009 \\
\hline $\mathrm{X}^{*}$ TENURE ${ }^{2}$ & $0.0000016 * *$ & 0.0000008 & $-0.0000018 * *$ & 0.0000007 \\
\hline X*DEFRATE & $0.207 * * *$ & 0.031 & $0.200 * * *$ & 0.032 \\
\hline $\mathrm{X}^{*}$ DEFRATE ${ }^{2}$ & $-0.014 * * *$ & 0.003 & $-0.014 * * *$ & 0.003 \\
\hline $\mathrm{R}^{2}$ & & 0.399 & & 0.398 \\
\hline $\mathrm{N}$ & & 10082 & & 10082 \\
\hline
\end{tabular}

Source: All data provided by CHINATEXTILE. Data are for 297 weavers at CHINATEXTILE during the 53-week period from the first week of April, 2003 to the last week of March, 2004. Notes:

All models include individual fixed effects and monthly time dummy variables.

***statistically significant at the $1 \%$ level

**statistically significant at the $5 \%$ level 


\section{Figure 1 The Slopes of the Earnings-Tenure Profiles}

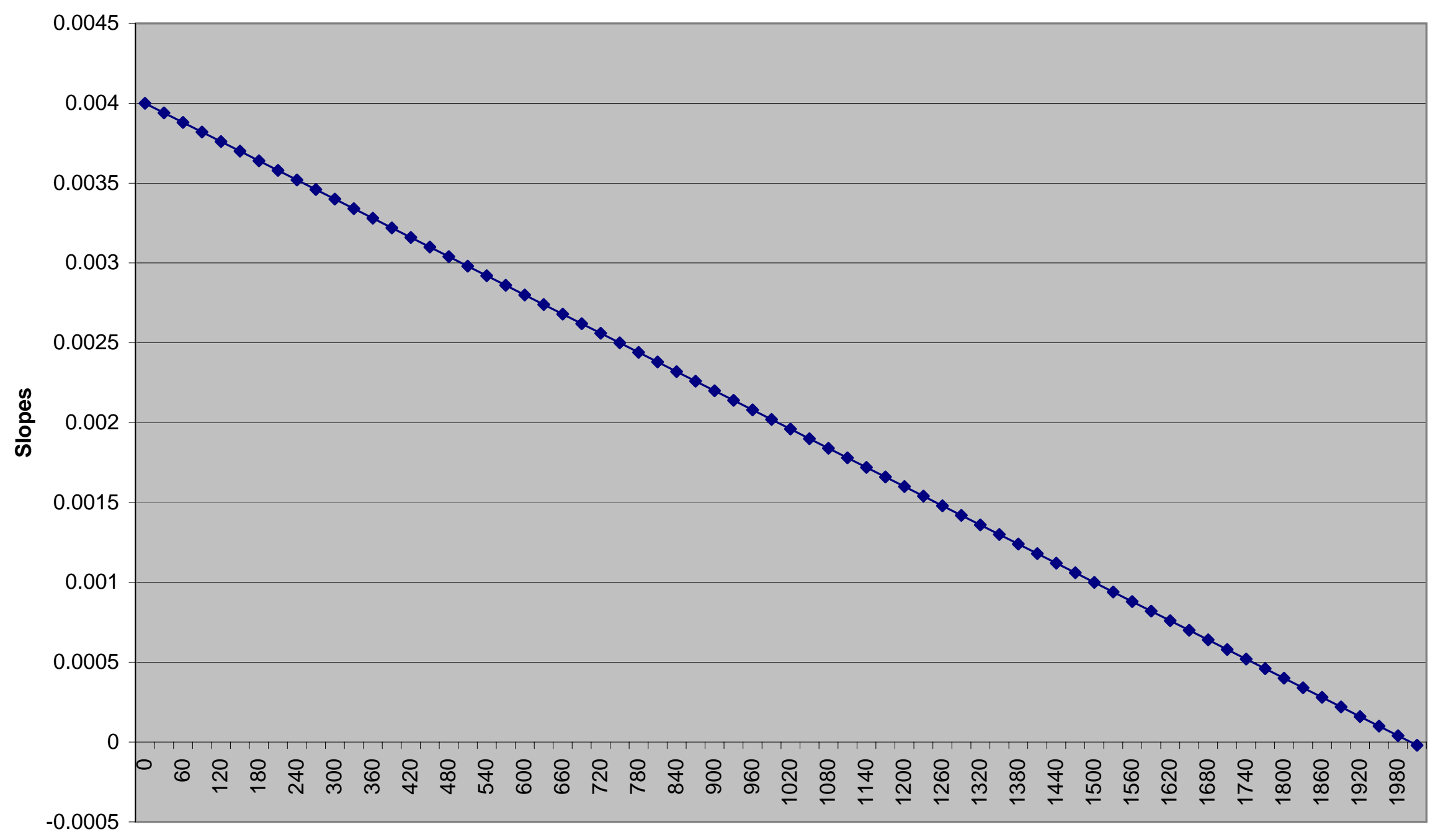

Tenure (in weeks) 